\title{
Research on the Necessity and Feasibility of Professional PE Courses in Colleges and Universities
}

\author{
Jing Bao \\ Physical Education Department \\ Northwest University \\ Xi'an, Shaanxi, China 710127
}

\begin{abstract}
At present, novel models of PE teaching emerge in large numbers in universities and collegesfrom theview of cultivating students' sports ability, paying attention to the development of students' cognition ability and student's emotional investment.However, with a view to the talent training goal and curriculum, it is almost blank researching on targeted professional PE curriculum based on the professional requirements of students in different majors.On the basis of requirements for qualities training in different majors and realizing the PE's physical exercise function in colleges and universities, it makes a research on the necessity and feasibility ofprofessional PE courses in colleges and universities, and demonstrates the multiple functions of PE in the PE teaching, so as to better play a role in training talents.At the same time, it is also hoped that more sports workers can pay attention and reflection on this issue to provide theoretical support for further deepening the implementation of teaching reform.
\end{abstract}

Keywords-PE teaching; professional PE curriculum; professional quality cultivation

\section{INTRODUCTION}

Since our country sets up higher education according to a certain major, the requirements for health of the students of different majors are consistent, but the ones for physical and psychological quality are different. For a long time, we have been emphasizing the modeling teaching content, expecting the students to achieve a relatively idealized standard when they graduate, regardless of whether their individual needs are the same[1].At present, novel models of PE teaching emerge in large numbers in universities and colleges from the view of cultivating students' sports ability, paying attention to the development of students' cognition ability and student's emotional investment. However, with a view to the talent training goal and curriculum, it is almost blank researching on targeted professional PE curriculum based on the professional requirements of students in different majors. Professor Chen Cuiran points in the Reform and Development of PE in Colleges and Universities that, "the requirements for basic quality and specification of qualified talents in the 21 st century must be fully studied before reform of teaching contents and curriculum. And it is necessary to study the requirements for basic quality and specification of qualified talents in different fields in the 21 st century according to the actual situation and characteristics of each major and take it as a basis for the reform[1].On the basis of requirements for qualities training in different majors, it makes a research on the necessity and feasibility of professional PE courses in colleges and universities, and demonstrates the multiple functions of PE in the PE teaching, so as to better play a role in training talents. At the same time, it is also hoped that more sports workers can pay attention and reflection on this issue to provide theoretical support for further deepening the implementation of teaching reform.

\section{STUdy OBJECT AND METHOD}

\section{A. Object of Study}

The study object is the students of 3 colleges and universities in Shaanxi province, of which the most is the undergraduates, accounting for $280(63.0 \%)$ and the second most is postgraduates, accounting for 167 (36.9\%).According to the distribution of their subjects, it includes $140(31.3 \%)$ students of research disciplines, $88(19.6 \%)$ of compound disciplines and $219(48.9 \%)$ of applied subjects.

\section{B. Methods of Study}

\section{1) Questionnaire survey}

According to the content and purpose of the study as well as the actual situation of the investigation and interview, with reference to the questionnaire survey of relevant literature, such as PE teaching curriculum and vocational practical PE curriculum, prepare the Questionnaire Survey of Professional PE Curriculum in Colleges and Universities, and invite several related discipline experts to assess its reliability and validity.

\section{2) Data statistics}

Build the original database for the data obtained by questionnaire with Excel 2003 and carry out descriptive statistics analysis with the software SPSS 17.0.

\section{RESUltS AND ANALYSIS}

\section{A. Analysis on the Necessity of Professional PE Courses in} Colleges and Universities

1) Current situation of PE in Chinese colleges and universities

With the development of the society and the society's increasingly-raised demand for the talent specification, the college PE teaching has been actively exploring the new trend 


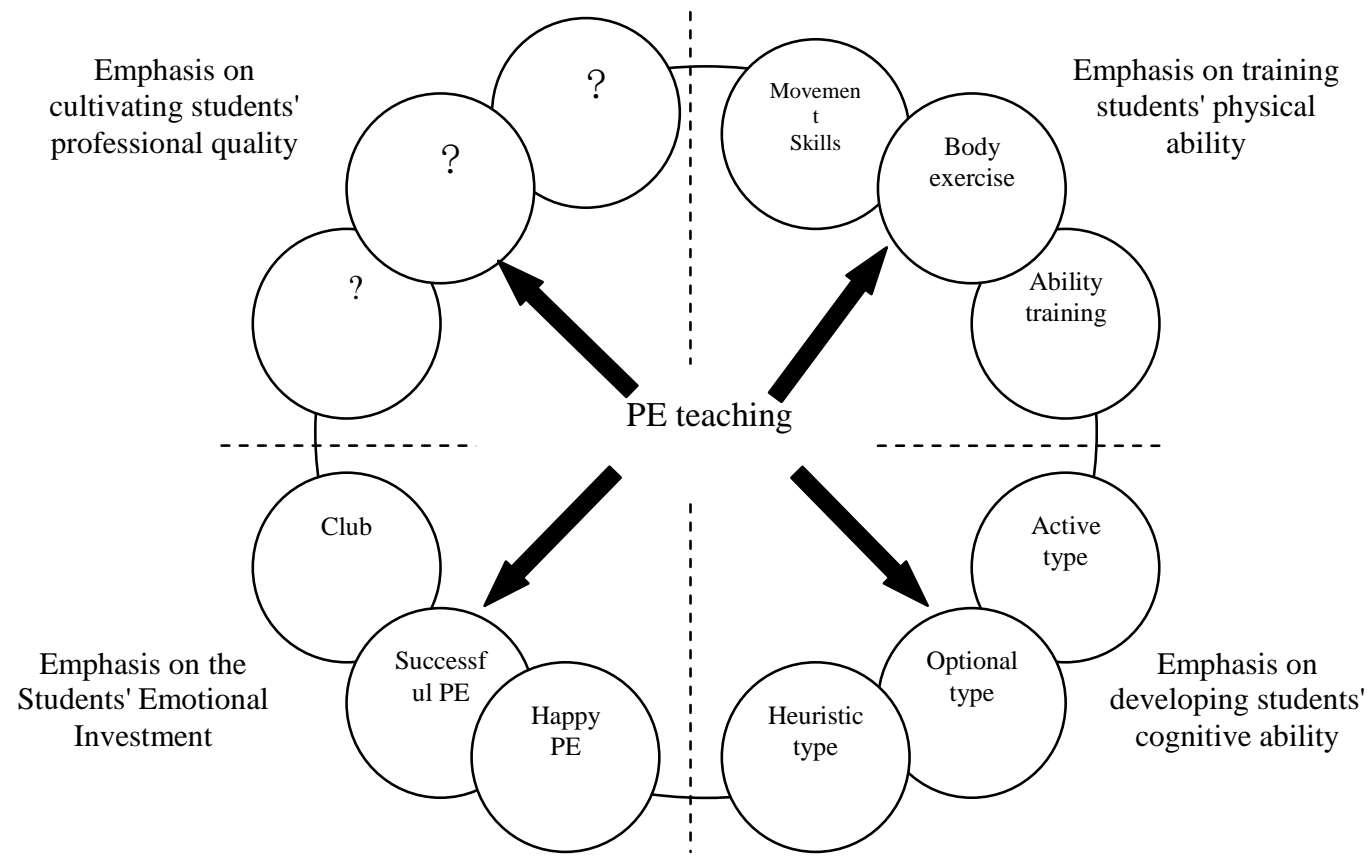

Fig. 1. Current Situation Analysis of PE Teaching.

As can be seen from Fig. 1, the current college PE teaching in our country is trending to a diversified development with a view to strengthening the student's physique and the cultivation of interest. However, the cultivation of professional quality of students in different majors as well as the objective reality that differences of the target and specification of talent training exist in different majors have always been neglected. Although the quality-oriented education has repeatedly emphasized the overall development of students, the current PE course till more concerns about how to teach and learn a technique, or how to practice body parts, than how should a "personhood" be cultivated, or how to improve one's quality both in body and mind through exercise, preferring physical to education that currently exists[1].It is worth us to think that when college English courses can develop from public English to professional English, and make more contributions to professional talents training closely according to professional characteristics and demand, whether PE teaching can step forward and make a similar attempt to professional PE course from public one.

Then, what is a professional PE course? PE major: it refers to PE curriculum special for training all kinds of professional PE talents. Professional PE: it refers to PE related to a particular occupation or discipline that its courses are set in accordance with the specific purpose and needs of the learner. The professional PE curriculum in this study is based on the training aim and the occupational demand of different disciplines and majors and pointedly trains the students' professional quality and professional ability by making use of the different functions of PE teaching in different sports.
2) Differences in the requirements of different disciplines for professional quality

In order to meet the needs of the society for talents, the society receives talents by majors, the country runs school by majors and the colleges and universities train talents by majors, all of which are aiming at providing professional talents[2].The society needs all kinds of special talents at all levels, and colleges and universities are the important guarantee for the output of professional talents. On the definition of the training aim of the students in colleges and universities, Mr. Hu Jianhua pointed in the Perspectives on Higher Education that, "the aim is to train students to meet the job requirement in the future and is the quality and ability of talents should be trained in professional education.[3]Colleges and universities shall combine the cultivation of talents with social needs and employment in the future, regardless of professional setting or training objective.

Through the collation and analysis of student questionnaire data, we can also draw a conclusion that differences exist in the requirements of different disciplines for professional quality, as shown in "Table I". 
TABLE I. DIFFERENCES IN THE REQUIREMENTS OF DIFFERENT DISCIPLINES FOR PROFESSIONAL QUALITY

\begin{tabular}{|c|c|c|c|c|c|}
\hline & $\begin{array}{l}\text { Very } \\
\text { Big }\end{array}$ & $\begin{array}{c}\text { A Little } \\
\text { Big }\end{array}$ & Normal & Small & $\begin{array}{c}\text { No } \\
\text { Difference }\end{array}$ \\
\hline $\begin{array}{l}\text { Number of } \\
\text { students } \\
\text { (overall) }\end{array}$ & 37 & 141 & 173 & 94 & 2 \\
\hline $\begin{array}{l}\text { Frequency } \\
(\%)\end{array}$ & $8.2 \%$ & $31.5 \%$ & $38.7 \%$ & $21 \%$ & $0.4 \%$ \\
\hline $\begin{array}{l}\text { Number of } \\
\text { students } \\
\text { (research } \\
\text { discipline) }\end{array}$ & 12 & 54 & 53 & 21 & 0 \\
\hline $\begin{array}{l}\text { Percentage } \\
(\%)\end{array}$ & $8.5 \%$ & $99.0 \%$ & $37.8 \%$ & $15 \%$ & $0 \%$ \\
\hline $\begin{array}{l}\text { Number of } \\
\text { students } \\
\text { (composite } \\
\text { discipline) }\end{array}$ & 10 & 24 & 35 & 19 & 0 \\
\hline $\begin{array}{l}\text { Percentage } \\
(\%)\end{array}$ & $11.3 \%$ & $27.2 \%$ & $39.7 \%$ & $21.5 \%$ & $0 \%$ \\
\hline $\begin{array}{l}\text { Number of } \\
\text { students } \\
\text { (applied } \\
\text { subject) }\end{array}$ & 15 & 63 & 85 & 54 & 2 \\
\hline $\begin{array}{l}\text { Percentage } \\
(\%)\end{array}$ & $6.8 \%$ & $28.7 \%$ & $38.8 \%$ & $24.6 \%$ & $0.9 \%$ \\
\hline
\end{tabular}

It can be seen from Table I that $8.2 \%$ of the students think their major's requirements for professional quality of having a big difference with other majors, and $31.5 \%$ of them think it is a little big difference, and $21 \%$ of the students think it is a small difference in the professional quality requirements. Through the above data analysis, on the one hand, due to the fact that students have limitations on other professional fields that it is difficult for them to make a comparison, so $38.7 \%$ of the students think the difference is normal. On the other hand, the students who are still in the learning stage are not deeply aware of the occupational direction of their majors in the future and the professional quality required for being employed. However, it can be seen from this study that $39.7 \%$ of students think there is a difference in the needs for professional qualities of different disciplines.

3) The current major curriculumis not able to fully meet the needs for students' professional quality

In the talents training of colleges and universities, it is often more emphasized in the cultivation of professional knowledge, skills and so on, while the cultivation of students' ability to adapt to the future employment is still deficient.

TABLE II. SATISFACTION OF STUDENTS' PROFESSIONAL QUALITY BY COURSES OFFERED BY MAJORS AND DISCIPLINES

\begin{tabular}{ccccccc}
\hline & & $\begin{array}{c}\text { Full } \\
\mathbf{y} \\
\text { Satis } \\
\mathbf{f y}\end{array}$ & $\begin{array}{c}\text { Better } \\
\text { Satisfie } \\
\mathbf{d}\end{array}$ & $\begin{array}{c}\text { Basical } \\
\text { ly } \\
\text { Satisfie } \\
\mathbf{d}\end{array}$ & $\begin{array}{c}\text { Not } \\
\text { Quite } \\
\text { Satisfie } \\
\mathbf{d}\end{array}$ & $\begin{array}{c}\text { Fail to } \\
\text { Satisfy }\end{array}$ \\
\hline $\begin{array}{c}\text { Open } \\
\text { Majo } \\
\text { r }\end{array}$ & $\begin{array}{c}\text { Numbe } \\
\text { r(of } \\
\text { student) }\end{array}$ & 7 & 76 & 214 & 134 & 16 \\
$\begin{array}{c}\text { Curri } \\
\text { culum }\end{array}$ & $\begin{array}{c}\text { Percent } \\
\text { age (\%) }\end{array}$ & $1.6 \%$ & $17.1 \%$ & $48.2 \%$ & $30.2 \%$ & $3.5 \%$ \\
\hline
\end{tabular}

We can see from the data in Table II that, only $1.6 \%$ of the students think the current curriculum can fully meet the needs of professional quality training. There are still $30.2 \%$ of students who believe that the major courses offered by the majors are not able to meet the needs of professional quality training, and $3.5 \%$ of the students think it can be satisfied. The analysis results show that the current university's major course education can meet the students' professional quality; however, in terms of the comprehensiveness, it still cannot completely meet the needs.

According to the research on the necessity and feasibility of professional PE courses in colleges and universities, $18 \%$ of students think that it is very necessary, $36 \%$ think it is necessary, and only a small number of students don't think it is necessary or completely unnecessary. As a result, it can be seen that most of the students agree to open professional PE curriculum, as shown in Table III:

TABLE III. NECESSITY OF OPENING PROFESSIONAL PE CURRICULUM

\begin{tabular}{ccccccc}
\hline & & $\begin{array}{c}\text { Very } \\
\text { Necess } \\
\text { ary }\end{array}$ & $\begin{array}{c}\text { Necess } \\
\text { ary }\end{array}$ & $\begin{array}{c}\text { Gen } \\
\text { eral }\end{array}$ & $\begin{array}{c}\text { Unnec } \\
\text { essary }\end{array}$ & $\begin{array}{l}\text { Comple } \\
\text { tely } \\
\text { Unnece } \\
\text { ssary }\end{array}$ \\
\hline $\begin{array}{c}\text { Open } \\
\text { Speci } \\
\text { alty }\end{array}$ & $\begin{array}{c}\text { Numbe } \\
\text { r(of } \\
\text { student) }\end{array}$ & 81 & 156 & 134 & 58 & 18 \\
$\begin{array}{c}\text { Cours } \\
\text { e }\end{array}$ & $\begin{array}{c}\text { Percent } \\
\text { age }(\%)\end{array}$ & $18 \%$ & $35 \%$ & $30 \%$ & $13 \%$ & $4 \%$ \\
\hline
\end{tabular}

In conclusion, it not only is necessary but also finds a new breakthrough point for the reform of PE in colleges and universities that pointedly cultivate the students' quality related to their majors and occupations in the future on the basis of the physical fitness function being realized by colleges and universities, according to the professional characteristics and the social needs, get students' general physical quality and development professional quality closely together and focus on the needs of students for their future development.

\section{B. Feasibility Analysis of Professional PE Curriculum in Colleges and Universities}

1) ProfessionalPE curriculum being set up to adapt to the teaching reform of colleges and universities

According to the Article 11 Identification of the main principles of the PE content in the Notification on Outline of Teaching Guidance for PE Course of Ordinary Colleges and Universities in China issued by the Ministry of Education in 2002, it points that we should consider both the need for actively adapting to the development of the personality of the students and the need to actively adapt to the development of the society. It should be convenient for students to conduct self-study and self-practice after school. In the Article 18 it states that, each school shall formulate the syllabus according to the actual situation of the school and the outline, choose the teaching content independently, and carry out the teaching reform and test in a reasonable way[4].The teaching idea of PE in colleges and universities will show an integrated trend, which should express the "multifunction" characteristics of PE while take comprehensive education and lifelong PE as main guiding ideology. Cultivate talents comprehensively and harmoniously developed in personality, ability, morality, intelligence, physical strength for the modern society and pursue the integrative value of PE[5]. The professional PE 
curriculum is to break the traditional concept of PE, make PE better combine with the students' quality, and play a bigger role in the full cultivation of talents."

\section{2) Different sport shave different effects on quality} training

In sports training, it is divided into collective project and individual item as one of the most basic classification method. Different sports items focus on different aspects in people's quality training. For example, single tennis combat makes it possible to positively influence the psychological quality of people in terms of intelligence, personality, mental health and so on. The tennis sports requires one with healthy psychological quality and high concentration of thought energy, and tennis learning is conducive to developing one's abilities to overcome frustration and stress as well as cultivating their attention concentration, will and body control; and in the meanwhile, tennis sports helps to cultivate one's taste and moral character[6].For basketball, it requires that many participants act as a whole, making timely and multiple communications and interactions with each other in order to better serve the common goals. It is possible to train the student's teamwork ability, the mental endurance and stress tolerance [7].The research shows that the group sports has good promoting effect in strengthening people's communication ability, improving interpersonal relationship and so on while the individual sports differs from group sports that each individual sports is a single unit less involved in communication when do sports. As a result, in terms of improving interpersonal communication, it has fewer advantages, but individual sports plays a prominent role in cultivating students' abilities of self-control, attention concentration, quick thinking and independence.[8]

3) Thetransferability of the teaching model of PE optional

Because of different requirements being made for professional quality cultivation of students in different majors, and according to different points in cultivation of students' qualities being different by different contents, methods and means of PE teaching, pointedly cultivate the students' quality related to their majors and occupations in the future on the basis of the physical fitness function being realized by colleges and universities, according to the professional characteristics and the social needs.

At present, the PE teaching in colleges and universities of our country is mostly carried out by form of "public course + optional course". Students choose PE course by their interest. We may take it into our consideration that whether we can replace their interest with requirements for professional quality. In this case, students should be given a full understanding of the following four things in the process of course selection making: first, their professional characteristics and professional quality requirements; secondly, which sports is able to play a role in the professional quality; thirdly, the special needs of the occupation in the future suitable for their major on social adaptation; and the last, the health knowledge of the relevant occupation as well as the way of continuing exercise after being employed, so as to realize lifelong PE. In this way, students choose to take into account the needs of their future development in addition to their individual interests.

\section{CONCLUSION AND RECOMMENDATIONS}

(1) At present, the PE in colleges and universities is still based on the students' physical and mental quality and from the student's interest angle, while from the view of the objective of talent cultivation and curriculum in colleges, the research on professional PE curriculum according to the professional quality requirements of different majors is almost blank.

(2) The differences of different disciplines' requirements for professional quality of students exist objectively. At present, the education of specialized course in colleges and universities can generally meet the requirement for students' professional quality, but still cannot meet it in terms of the comprehensive training of students' professional competence.

(3) Different sports items focus on different aspects in people's quality training. For example, the group sports has good promoting effect in strengthening people's communication ability, improving interpersonal relationship and so on while the individual sports is a single unit less involved in communication when do sports, but individual sports plays a prominent role in cultivating students' abilities of self-control, attention concentration, quick thinking, independence and resilience.

(4) It can help students feel that PE is helpful to their professional study and future work and improve the students' learning initiative to select practical PE teaching contents when formulating PE teaching plans and contents, according to the characteristics of the students' majors and different sports.

\section{REFERENCES}

[1] Song Jixin. Research on Sports Integrated with Science and Colure[J] Journal of Physical Education 2004, 11 (1).

[2] Feng Yan. An Exploratory Study on College Students' Physical and Quality Education in the 21st Century [J] China Sport Science, 2001( 4)

[3] $\mathrm{Hu}$ Jianhua, etc. Perspectives on Higher Education [M] Jiangsu Education Publishing House

[4] Notification on Outline of Teaching Guidance for PE Course of Ordinary Colleges and Universities in China issued by the Ministry of Education[z]. Beijing: Ministry of Education document (J.T.Y.[2002]No. 13): 6-9

[5] Zhou Hongping. A General Review on the Reform of Physical Education in Colleges and Universities Since the 1980s[J].JournalofSportsandScience: 2001( 22) 1

[6] Wu Guangjun. Effects of Tennis Learning on the Cultivation of Psychological Quality[J]. Quality Education, 2011 (1)

[7] Liu Xiaosong. Reflection on the Influence of Basketball Teaching on Cultivation of Students' Comprehensive Quality [J]

[8] Ren Changshun. investigation and research on the influence of different sportson the mental health of college students[J] Journal of Harbin Institute of Physical Education. 2004( 4). 